Original Research Paper

\title{
Analysis of Urban Flora of the City of Almaty (Kazakhstan)
}

\author{
${ }^{1}$ Gulbanu Aueskhanovna Sadyrova, ${ }^{2}$ Zarina Arkenzhanovna Inelova, \\ ${ }^{3}$ Saule Melsovna Dzhamilova, ${ }^{3}$ Duman Kulakhmetovich Baizhygitov, \\ ${ }^{2}$ Zura Yessimsitova and ${ }^{4}$ Marzhankul Myrzakhmetovna Dauletbaeva \\ ${ }^{1}$ Institute of Botany and Phytointroduction, 050040, Kazakhstan, Almaty, Timiryazev street, 36, Kazakhstan \\ ${ }^{2}$ Al-Farabi Kazakh National University, 050040, Kazakhstan, Almaty, al-Farabi Ave, 71, Kazakhstan \\ ${ }^{3}$ Abai Kazakh National Pedagogical University, 050010, Kazakhstan, Almaty, Dostyk Ave., 13, Kazakhstan \\ ${ }^{4}$ University of Technology, 050012, Kazakhstan, Almaty, Tole bi street, 100, Kazakhstan
}

Article history

Received: 30-01-2018

Revised: 09-06-2018

Accepted: 24-09-2018

Corresponding Author: Gulbanu Aueskhanovna Sadyrova

Institute of Botany and Phytointroduction, 050040, Kazakhstan, Almaty, Timiryazev street, 36, Kazakhstan

E-mail: gulbanu-s@mail.ru
Abstract: The article contains information about the composition of urban floras in Almaty. It was revealed, that urban flora of Almaty is represented by 396 species belonging to 204 genera and 73 families. The basis of the urban flora of the city of Almaty is angiosperms $(92,0 \%)$, gymnosperms are represented in the flora in 31 species $(7,8 \%)$ and 1 species represented by ferns $(0,25 \%)$. The class Liliopsida (monocotyledonous) is represented by 4 families or $5,4 \%$. Class Magnoliopsida (dicotyledonous) is represented by 67 families or $91.7 \%$. In the gardening of Almaty city, there are 54 species $(25,3 \%)$ of trees and shrubs of the local (natural) flora of Kazakhstan ( 9 coniferous and 45 hardwoods) from 33 genera and 19 families. In the gardening of Almaty city 159 species $(74,6 \%)$ of woody and shrub introducents are used, that is, plants grown in the soil outside the range of their natural distribution. Of these, 22 are coniferous and 137 hardwoods of 61 genera and 34 families.

Keywords: Flora of Almaty, Magnoliopside Class, Liliopids Class, Trees and Shrubs of Local (Natural) Flora, Wood and Shrub Introductions

\section{Introduction}

Currently, urbanization is one of the main trends of human development. The increase in the population, the growth in the number of cities and territories that they occupy, have taken on a global scale. Today in the cities of the world live up to $60 \%$ of the population, whereas in comparison with 1950 , the urban population was only less than $30 \%$ (The territorial body of the Federal State Statistics Service for the Republic of Mari El, n. d.). The city has a huge impact on the natural environment and all its components, changing the climate, relief, hydrological regime, soil cover, flora and fauna. In large cities, under the influence of various anthropogenic factors, the natural conditions of the environment, species composition and their ratio change. Plants are an integral part of ecosystems, so the study of urban floras and the features of their formation is one of the current trends in modern floristry (Yurtsev and Kamelin 1987). The most widespread anthropogenic factors in urbanized ecosystems include the impact of harmful emissions from plants and factories, road transport, industrial waste and others. In cities, as elsewhere, processes of movement of plant species are activated. It is cities that are the centers of the concentration of adventive plants and it is often from cities that the introduction of allotment species into other regions and regions begins. It is cities that are the centers of the concentration of adventive plants and it is often from cities that the introduction of allotment species into other regions. In connection with the active growth of cities, the development of new territories, the changing of landscapes and the transformation of natural ecosystems, the question arises of the stability of the transformed ecosystems and their functioning in new, unusual conditions. Therefore, at the present stage, it is necessary to study various aspects of the functioning of urban landscapes, in order to prevent the complete destruction of already changed ecosystems. The city suffers because of the severe air pollution, the large influx of rural population into the city, the growing overpopulation of certain urban areas, the desire of the population to live closer to the city center and not on its outskirts. 
At present, the territory of Almaty is divided into 8 regions: Almaly (1), Turksib, Bostandyk, Medeu, Alatau, Nauryzbay, Auezov and Zhetysu (Fig. 1). To date, more than 8,000 hectares of the city's territory are occupied by gardens and parks, squares and boulevards.
Below is a list of parks, squares, boulevards, green areas in Almaty. As can be seen from Fig. 2, the analysis of the number of parks, boulevards, public gardens, avenues and green zones in the eight study areas of Almaty showed their uneven distribution by districts.

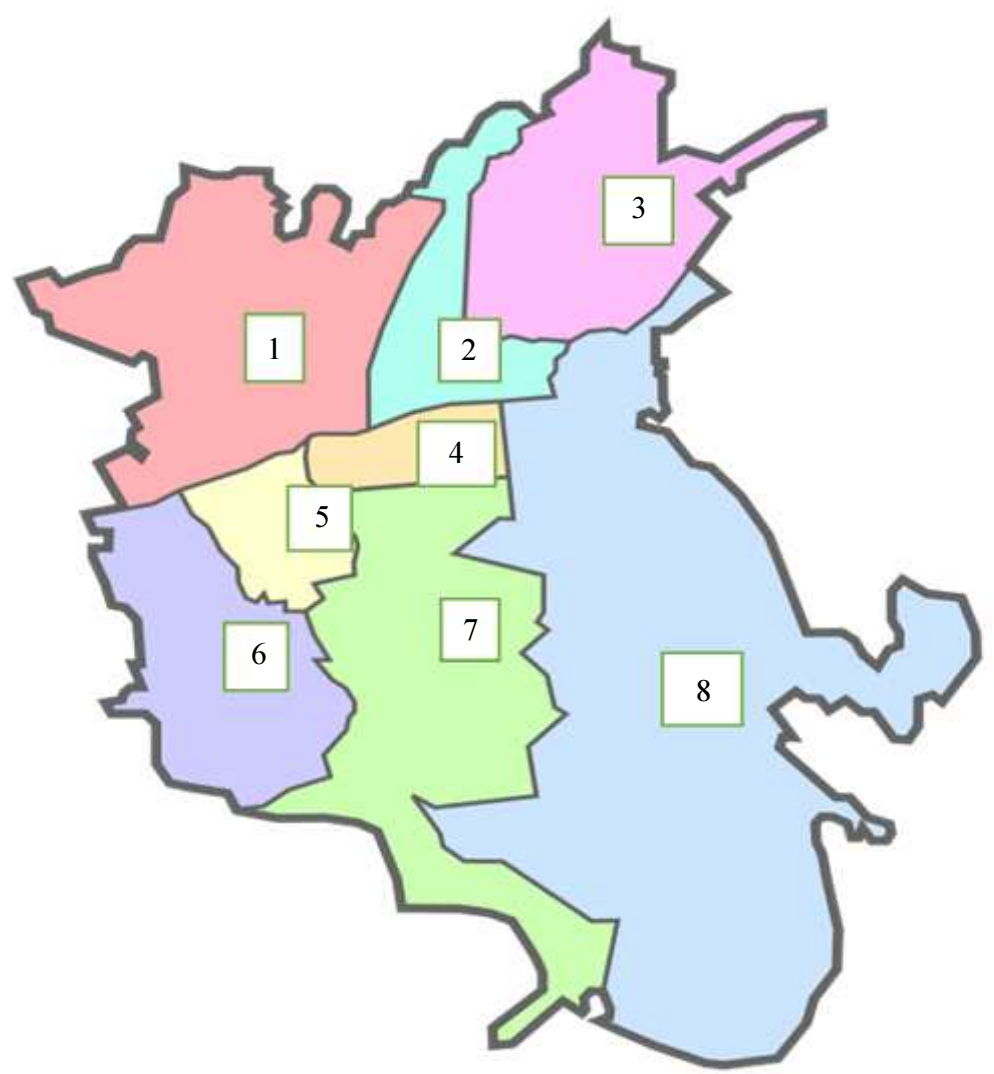

Fig. 1: Schematic plan of Almaty city; 1. Alatau, 2. Zhetysu, 3. Turksib, 4. Almaly, 5. Auezov, 6. Nauryzbay, 7. Bostandyk, 8. Medeu districts

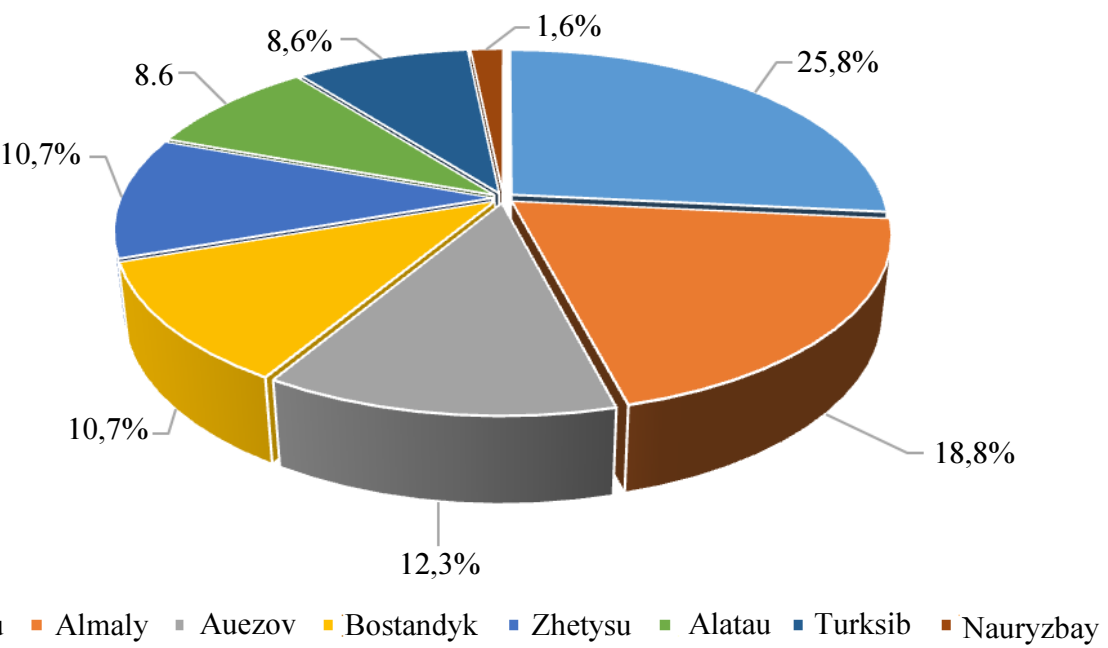

Fig. 2: Percentage of parks, boulevards, public gardens, alleys and green zones in eight districts of Almaty 

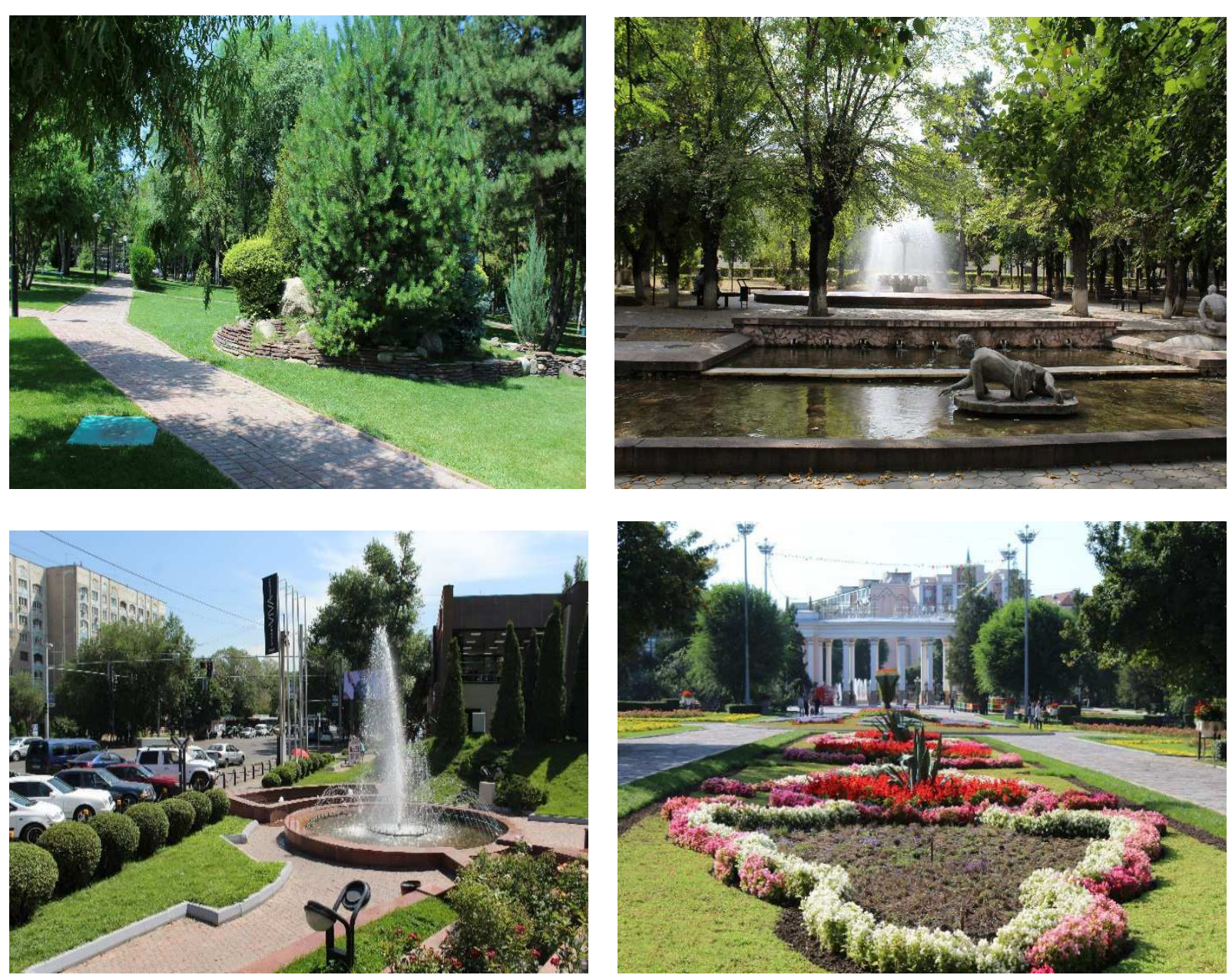

Fig. 3: Almaty city

The first place in the number of parks, boulevards, public gardens, avenues and green areas occupies the Medeu district, the total number of which is 48 , which is $25,8 \%$. The second place in the number of parks, boulevards, squares and green areas is occupied by the Almaly district, totaling 35 , which is $18,8 \%$. In the third place in the number of parks, boulevards, squares and green areas is Auezov district only 23 or $12,3 \%$. Fourth place in the total number of parks, boulevards, squares and green spaces occupy Bostandyk and Zhetysu districts of 20 (10,7 The fifth place is occupied by the Turksib and Alatau districts by $16(8,6 \%)$. And the smallest number of parks (1) and green areas (2), only 3 is in Nauryzbay district and is $1,6 \%$ (Fig. 3). The city of Almaty is located in the center of the Eurasian continent, in the southeast of the Republic of Kazakhstan. Almaty is unique in its physico-geographical and natural climatic characteristics, which form the ecological features of its territory. The city of Almaty is located in the foothills of the Zailiysky Alatau, the total area of which is more than 683,51 square kilometers. The population of the city of Almaty as of June 01. 2017 is 1768303 people (The population of Almaty is approaching 2 million people, n. d.).

Almaty is characterized by a rather complicated ecological situation due to its location in the foothill hollow. The formation of fogs excludes vertical mixing of air layers of the atmosphere. Climatic features create unfavorable conditions for dispersion of impurities from low emission sources, harmful substances accumulate in the surface layer of the atmosphere and take part in the formation of smog. Complex landscapegeographical conditions determined the modern planning structure of the city. A significant part of the city is occupied by residential areas. In the central part of the city there is a large part of all objects of social, cultural and domestic use. In conditions of weak natural ventilation and a large number of mobile and stationary sources, atmospheric air pollution is the most urgent environmental problem in the city of Almaty. In conditions of weak natural ventilation and a large 
number of mobile and stationary sources, atmospheric air pollution is the most urgent environmental problem in the city of Almaty. In this regard, monitoring of green plantations in the city, including inventory and assessment of the current state of the flora, is very relevant (What will save Almaty from smog, 2016; The Almaty-2020 Development Program, n. d.)

The city of Almaty is one of the oldest and largest cities in the country, having a thousand-year history.

On the territory of the city of Almaty in different years worked scientists who made a significant contribution to the formation of urban flora.

According to archival data, the settlers from the Kursk region began to deal with the landscaping of the city of Verny and in 1868 the «Kazenny Garden» (now the Central Park of Culture and Rest) was founded on the initiative of Governor-General I.A. Kolpakovsky.

On his own initiative, the Vernensky Grove (Baum grove), the Pushkin Gardens (Park of 28 Panfilov guardsmen) were created. In the State Garden and the Vernensky Grove there were nurseries of wood and shrubby species, from which a lot of seedlings for the planting of greenery were released free of charge to the population. In the State Garden were planted fruit trees, ornamental trees and shrubs (Lukhtanov, 2014; Parks and public gardens of Almaty 1917-1991).

It should be noted that the green fund of the city of Almaty, which was formed under the influence of natural and geographical and historical conditions, included naturally growing forests and tree and shrub massifs of the foothills of the Zailiysky Alatau.

Despite the long history of studying the flora and vegetation of the Zailiysky Alatau, no specialized works on the study of urban floras in Almaty have been conducted to date.

\section{Materials and Methods of Research}

The object of our study was the urbanized flora of Almaty (Table 1).

Table 1: Total number of parks, squares, boulevards, green areas in Almaty

\begin{tabular}{|c|c|c|c|c|c|c|}
\hline \multirow[b]{2}{*}{ Districts } & \multicolumn{6}{|l|}{ Name } \\
\hline & Parks & Groves & Alleys & Boulevards & Squares & $\begin{array}{l}\text { Green } \\
\text { areas }\end{array}$ \\
\hline Almaly & 1 & - & - & 9 & 21 & 4 \\
\hline Auezov & 1 & - & - & 1 & 6 & 15 \\
\hline Zhetysu & 2 & 1 & - & - & 6 & 13 \\
\hline Alatau & - & - & 1 & & 16 & 14 \\
\hline Bostandyk & 3 & - & - & 5 & 10 & 2 \\
\hline Medeu & 3 & 1 & - & 9 & 30 & 7 \\
\hline Nauryzbay & - & - & - & - & 1 & 2 \\
\hline Turksib & 2 & - & 2 & 1 & 10 & 1 \\
\hline Total: & 12 & 2 & 3 & 25 & 100 & 58 \\
\hline
\end{tabular}

\section{The Purpose of the Research}

To study the species composition of the urbanized flora of Almaty.

\section{Research Tasks}

1. To conduct an inventory of the species composition of urban flora in Almaty

2. To conduct taxonomic, geographical, biomorphological, analysis of urban floras in Almaty

Classical and traditional methods of botanical and floral studies were used to study the urbanized flora of Almaty. In different periods of spring, summer and autumn vegetation seasons (from April to September), pedestrian routes were used.

Collection of herbarium material was carried out according to the method of Skvortsov (1977). Books were used to determine plant species, the distribution range and the origin of plant species: Flora of the USSR (19341964), Trees and Shrubs of the USSR (1966), Flora of Kazakhstan (1956-1966), Trees and Shrubs of Kazakhstan (1966), "Plants of Central Asia" (1963-1989), "The determinant of plants of Central Asia"(1968-1993), "Illustrated determinant of plants in Kazakhstan"(19621975), The determinant of plants on-line. An open atlas of vascular plants in Russia and neighboring countries (http://www.plantarium.ru), Illustrated flora of the Northeastern united states and adjacent Canada (1898), The geography of plants (1986), Flora of North America (1920), Flora of China (2013) and others.

To clarify the species and generic names, the last reports of Cherepanov (1981), Abdulina (1998). Types of life forms were carried out according to the classifications of Raunkire and Serebryakov (Serebryakov, 1962). The types of areals of the investigated plant species are identified according to the classifications developed by Lavrenko and Nikolskaya (1963), Tolmachev (1974), Kamelin (1990), Goloskokov (1949).

Herbarium material was collected during the entire growing season, the same places were visited repeatedly for the maximum collection of herbarium specimens. The herbarium funds of the Institute of Botany and PhytoIntrusion of the Ministry of Education and Science of the Republic of Kazakhstan, the Department of Biodiversity and Bioresources of the KazNU, Al-Farabi.

The inventory of urban flora in Almaty was conducted by us within the administrative boundaries of cities.

\section{Research Results}

Work on studying the flora of Almaty was conducted by us during 2015-2017. Despite the fact that the floras of cities are largely similar, each city has its own original urban flora, the composition of which is determined by its history, modern condition and natural conditions. 
Special studies to study urban floras in Almaty and other cities of Kazakhstan have not been carried out to this day.

For the first time we carried out a complete inventory of the species composition of vascular plants in Almaty.

Analysis of tree-shrub species of urban flora in Almaty showed that in the parks, boulevards, squares, along the streets, the overwhelming part of trees and bushes are introduced species, the rest include herbaceous vegetation (perennials, annuals) and a small part of trees and shrubs local species. 35 species - massive, which grow on all the streets, boulevards, squares of the city - this is mostly foreign. These include: Populus nigra, Populusitalica, Populus alba, Populus balsamifera, Fraxinus excelsior, Fraxinus pennsylvanica, Fraxinus americana, Betula pendula, Acer negundo, Acer platanoides, Acer pseudoplatanus, Tilia cordata, Tilia mandshurica, Aesculus hippocastanum, Ulmus parvifolia, Ulmus laevis, Ulmus glabra, Gleditsia triacanthos, Acacia albida, Quercus robur, Pitaaa bies, Pinus sylvestris, Pinus pallasiana,
Larix gmelinii, Berberis vulgaris, Syringa vulgaris, Ligustrum vulgare, Viburnum opulus, Philadelphus coronarius, Thujao ccidentalis and others. Of the native species - Armeniaca vulgaris, Prunus sogdiana, Fraxinus sogdiana, Malus niedzwetzkyana, Malus sieversii, Rhamnus cathartica, Picea schrenkiana, Crataegus chlorocarpa, Spiraea hypericifolia, Juniperus sabina, Juniperus turkestanica and others (Fig. 4).

Many interesting species are introduced singly, but they grow mainly in the parks of Almaty.

A variety of parks and some public gardens and streets of Almaty. If in the Soviet years more planted fruit trees, now preference is given to many decorative woody and shrubby species.

As a result of our research for 2015-2017 urban flora of Almaty districts, a summary of flora of higher vascular plants in Almaty was compiled with at least 396 species belonging to 204 genera and 73 families.

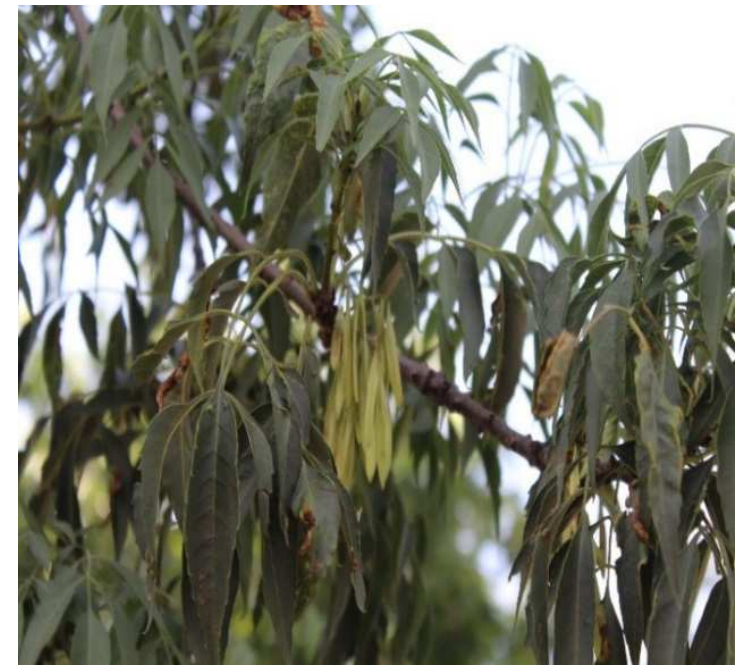

(a)

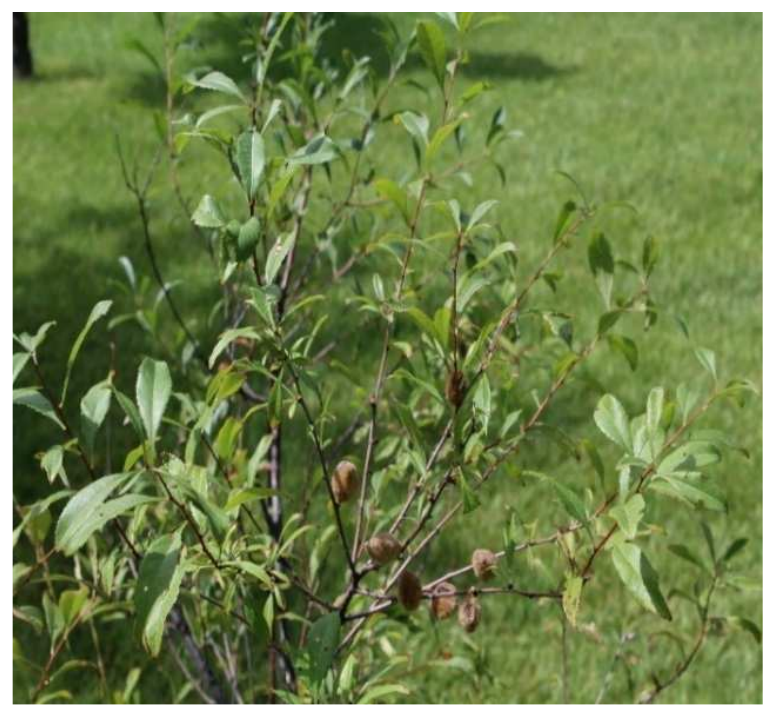

(c)

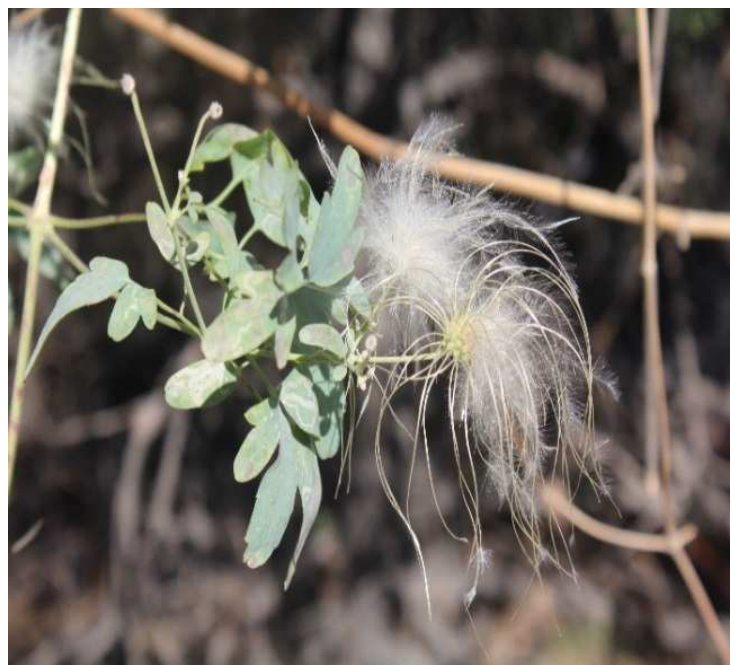

(b)

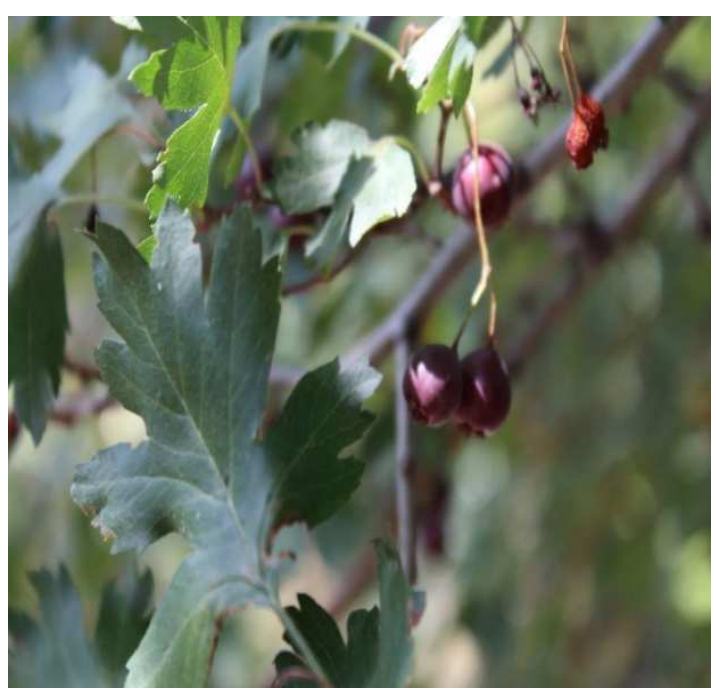

(d) 


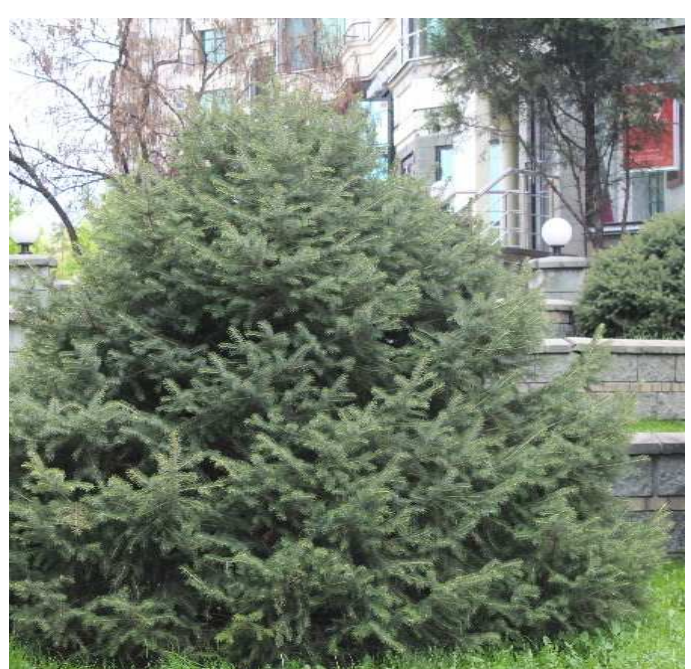

(e)

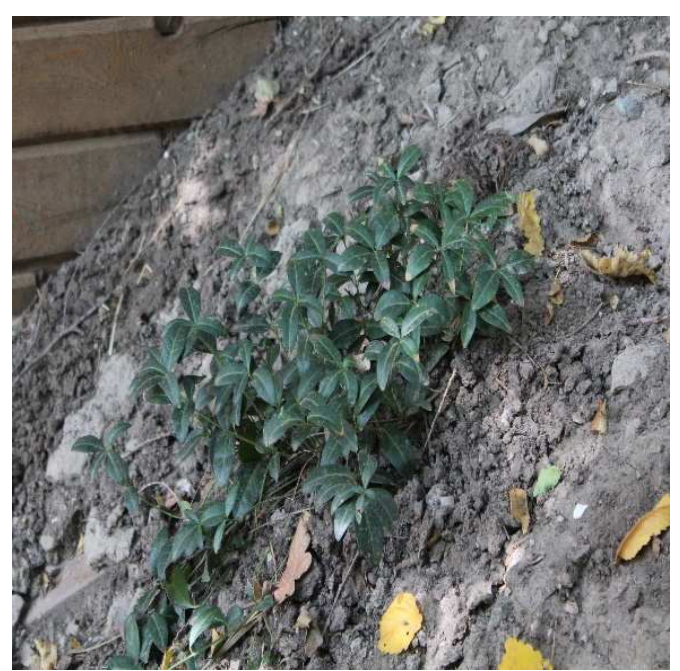

(f)

Fig. 4: Tree and shrub plants of the local flora of Almaty (a) Fraxinus sogdiana Bunge (b) Clematis orientalis L. (c) Amygdalus petunnikowii Litv (d) Crataegus songarica K. Koch. (e) Picea schrenkiana Fisch. and C.A. Mey. (f) Euonymus semenovii Regel and Herder

\section{Taxonomic Analysis}

Analysis of the taxonomic structure showed the absence in the urban flora of Almaty of the plumaceous and a relatively weak representation of vascular sporic horsetails - ferns - Dryopteris filixmas (L.) Schott (Fig. 5).

The basis of urban flora in Almaty, as seen in Fig. 5, is Magnoliophyta (angiosperms), which accounts for 92,0\% and only a small number of species refers to Pinophyta (gymnosperms) 31 or $7.8 \%$ and a very negligible percentage of Polypodiophyta (ferns) 1 or $0,25 \%$.

The Liliopsida class (monocotyledonous) is represented by 4 families $(5,4 \%$ of the total number of families), 25 genera $(12,3 \%)$ and 31 species $(7,8 \%)$, Magnoliopsida (dicotyledonous) - 67 families $(91,7 \%), 168$ genera $(82,3 \%)$ and 364 species or 92,0\%. Among the gymnosperms Picea schrenkiana, P. obovate, Abies sibirica, Pinus sylvestris, Larix sibirica, Juniperus sabina, $J$. communis, $J$. turkestanica and J. sibirica belong to aboriginal, i.e. and the remaining $26(6,5 \%)$ species are cultivated plants: Pinus pallasiana, Pinus nigra, Pinus mugo, Picea glauca, Picea punpens, Thuja occidentalis, Juniperus scopulorum, Juniperus virginiana, Pseudotsuga menziesii, Larix gmelinii and others.

The taxonomic structure of urban floras in Almaty is presented in Table 2.

Analysis of the largest families of the flora of Almaty made it possible to identify 21 leading families (according to the largest number of species) (Table 2), where only tree-shrub species are included in the introduced flora and herbaceous plants are included in the native flora other than woody-shrubby species.

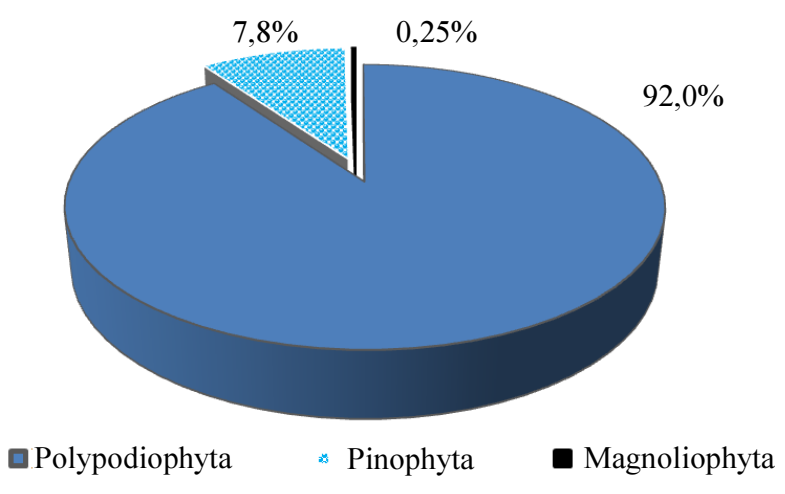

Fig. 5: The ratio of systematic groups of urban floras in Almaty

The leading families of the entire flora of Almaty in descending order are represented by the following list: Rosaceae $\rightarrow$ Asteraceae $\rightarrow$ Poaceae $\rightarrow$ Pinaceae $\rightarrow$ Fabaceae $\rightarrow$ Brassicaceae $\rightarrow$ Scaphulariaceae $\rightarrow$ Salicaceae $\rightarrow$ Cupressaceae $\rightarrow$ Aceraceae $\rightarrow$ Caprifoliaceae $\rightarrow$ Lamiaceae $\rightarrow$ Oleaceae $\rightarrow$ Ranunculaceae $\rightarrow$ Malvaceae $\rightarrow$ Polygonaceae $\rightarrow$ Berberidaceae $\rightarrow$ Grossulariaceae $\rightarrow$ Ulmaceae $\rightarrow$ Rhamnaceae $\rightarrow$ Viburnaceae $\rightarrow$ Juglandaceae $\rightarrow$ Elaeagnaceae $\rightarrow$. Cornaceae $\rightarrow$ Vitaceae. Quantitatively, they are expressed in Table 3 .

Table 3 shows that the sixteen leading families of the urban flora of the investigated territory of the eight districts of Almaty consist of 159 genera and 312 species, their specific gravity in the composition of urban flora is high and amounts to $78.2 \%$ of the total number of species.

With the traditional calculation for the 10 largest families (used in the analysis of flora), more than half $(62,0 \%)$ of the entire urban flora of Almaty is accounted for. 
Table 2: Number of species in the leading families of the flora of Almaty

\begin{tabular}{|c|c|c|c|c|}
\hline \multirow[b]{2}{*}{ No. } & \multicolumn{2}{|l|}{ Introduced flora } & \multicolumn{2}{|c|}{ Aboriginal (local) flora } \\
\hline & Families & Number of species & Families & Number of species \\
\hline 1 & Rosaceae & 42 & Asteraceae & 25 \\
\hline 2 & Pinaceae & 15 & Rosaceae & 19 \\
\hline 3 & Salicaceae & 11 & Brassicaceae & 11 \\
\hline 4 & Caprifoliaceae & 10 & Pinaceae & 5 \\
\hline 5 & Fabaceae & 7 & Polygonaceae & 5 \\
\hline 6 & Aceraceae & 7 & Cupressaceae & 4 \\
\hline 7 & Oleaceae & 7 & Scrophulariaceae & 4 \\
\hline 8 & Cornaceae & 4 & Chenopodiaceae & 3 \\
\hline 9 & Berberidaceae & 4 & Betulaceae & 3 \\
\hline 10 & Hydrangeaceae & 4 & Salicaceae & 2 \\
\hline 11 & Juglandaceae & 3 & Plantaginaceae & 2 \\
\hline 12 & Bignoniaceae & 3 & Tamaricaceae & 2 \\
\hline 13 & Anacardiaceae & 3 & Ulmaceae & 2 \\
\hline 14 & Grossulaceae & 3 & Grossulaceae & 2 \\
\hline 15 & Vitaceae & 3 & Malvaceae & 2 \\
\hline 16 & Viburnaceae & 3 & Aceraceae & 2 \\
\hline 17 & Sambucaceae & 2 & Fabaceae & 2 \\
\hline 19 & Tiliaceae & 2 & & \\
\hline 20 & Ulmaceae & 2 & & \\
\hline 21 & Rutaceae & 2 & & \\
\hline Total: & & 137 & & 97 \\
\hline
\end{tabular}

Table 3: Leading families of common urban floras in Almaty

\begin{tabular}{lccc}
\hline Families & Number of genera & Number of species & \% of the total number of species \\
\hline 1. Rosaceae & 23 & 71 & 18,2 \\
2. Asteraceae & 25 & 35 & 9,0 \\
3. Poaceae & 22 & 28 & 7,2 \\
4. Pinaceae & 7 & 20 & 5,1 \\
5. Fabaceae & 14 & 16 & 4,0 \\
6. Brassicaeae & 14 & 15 & 3,8 \\
7. Scrophulariaceae & 3 & 14 & 3,6 \\
8. Salicaceae & 2 & 13 & 3,3 \\
9-10. Cupressaceae & 2 & 10 & 2,5 \\
9-10. Aceraceae & 1 & 10 & 2,5 \\
9-10. Caprifoliaceae & 4 & 10 & 2,5 \\
11. Lamiaceae & 8 & 9 & 2,3 \\
12. Oleaceae & 3 & 8 & 2,0 \\
13. Ranunculaceae & 5 & 7 & 1,8 \\
14-15. Malvaceae & 5 & 6 & 1,5 \\
14-15. Polygonaceae & 5 & 5 & 1,5 \\
16-17. Berberidaceae & 2 & 5 & 1,2 \\
16-17. Grossulariaceae & 2 & 5 & 1,2 \\
16-17. Ulmaceae & 2 & 4 & 1,2 \\
14-15. Juglandaceae & 1 & 4 & 1,0 \\
13-14. Elaeagnaceae & 2 & 4 & 1,0 \\
13-14. Cornaceae & 2 & 4 & 1,0 \\
13-14. Vitaceae & 2 & 4 & 1,0 \\
13-14. Apiaceae & 4 & 312 & 1,0 \\
Total: & 159 & & 78,2 \\
\hline
\end{tabular}

The first place in the urban flora of the investigated territory of the eight districts of Almaty is occupied by the Rosaceae family, it should be noted that the vast majority of the species of this family are inorionic. The leading position in the flora of Almaty is occupied by the family Pinaceae where a significant number of species of this family belongs to the North American and European flora. A large percentage of the species are Asteraceae, Poaceae, the fifth place is occupied by the Fabaceae family and the sixth place in the spectrum of the leading 
families in the urban flora of the eight districts of Almaty is occupied by the Brassicaceae family, the abundance of which is formed due to weed plants. In seventh place is the family Scrophulariaceae (14 species). It is also necessary to note the high position of the families Salicaceae (13 species), Cupressaceae (10 species), Aceraceae (10 species) and Aceraceae (10 species). They are located at the eighth, ninth tenth and eleventh places. A significant number of species are represented by the families Lamiaceae, Oleaceae, Ranunculaceae, Malvaceae, Polygonaceae, Berberidaceae, Grossulariaceae, Caprifoliaceae and Ulmaceae, which contain five species or $1.2 \%$ (Table 4 ).

Analysis of the largest genera of urban floras in Almaty showed that the number of species by the largest genera were: Crataegus, Spiraea and Veronica which contain 11 species. In the second place is the genus Acer of 10 species. In third place are Juniperus and Populus - 9 species, followed by the genus Picea and Pinus in 7 species. Six species have the genera Rosa, Syringa. The genus Fraxinus and Artemisia contain 5 species. Four species have genera Ulmus, Salix, Juglans, Malus, Prunus, Ribes, Berberis.

In these twelve genera, there are 97 species (24,5\%). Fifteen genera: Cerasus, Pyrus, Elaeagnus, Sorbus, Padus, Cerasus, Vitis, Viburnum, Lonicera, Cotoneaster, Centaurea, Poa, Taraxacum, Potentilla, Prunus contain 3 species. In 2 species contain fortyone genus. These include: Aquilegia, Paeonia, Corydalis, Chenopodium, Polygonum, Betula, Viola, Tamarix, Brassica, Tilia, Malva, Euphorbia, Cirsium, Amelanchier, Amygdalis, Viburnum, Trifolium, Vicia, Rhus, Impatiens, Euonymus, Cuscuta, Catalpa, Plantago, Mentha, Sambucus, Forsythia, Hyoscyamus, Cotoneaster, Bromus, Festuca, Agrostis, Hordeum, Larix, Morus, Clematis, Urtica, Arctium, Sonchus, Agrostis, Cardamine.
Genera containing one species there are 133. These are Armeniaca, Ailanthus, Acacia, Gliricidia, Phellodendron, Celtis, Cedrus, Hippophae, Abies, Pseudotsuga, Platanus, Gymnocladus, Quercus, Cotinus, Aesculus, Gleditsia, Tsuga, Thuja, Amorpha, Aronia, Ligustrum, Buddleja, Platycladus, Weigela, Hibiscus, Hydrangea, Cornus, Daphne, Genista, Deutzia, Parthenocissus, Bunias, Chaenomeles, Cydonia, Campsis, Caragana, Penthaphylloides, Atraphaxis, Lecpedeza, Mahonia, Rubus, Ptelea, Physocarpus, Buxus, Symphoricarpos, Taxus, Philadelphus, Humulus, Ambrosia, Conium, Glechoma and others.

The distribution of introducents and aborigines (local) among tree and shrub species of Almaty showed that among tree and shrub species 54 species $(25,3 \%)$ represent the natural flora of Kazakhstan (9 conifers and 45 deciduous species) from 33 genera and 19 families. 159 species $(74,6 \%)$ are introducents, that is, plants grown in the soil outside the range of their natural distribution (Fig. 6). Of these, 22 species of coniferous and 137 species of hardwood from 61 genera and 34 families.

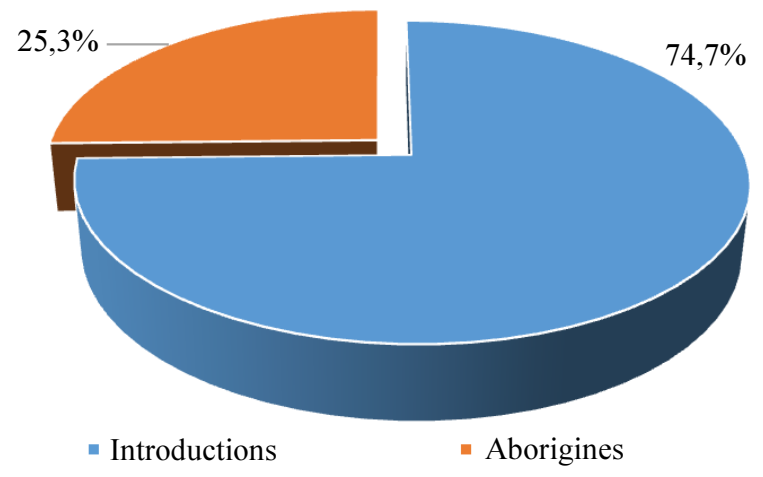

Fig. 6: Distribution of introductions and aborigines among tree-shrub species of Almaty city

Table 4: The largest kind of urban floras in Almaty

\begin{tabular}{lcc}
\hline Genera & Number of species & \% of the total number of species \\
\hline 1-2.Crataegus & 11 & 2.8 \\
1-2.Spiraea & 11 & 2.8 \\
1-2. Veronica & 11 & 2.8 \\
3. Acer & 10 & 2.5 \\
4-5. Populus & 9 & 2.3 \\
4-5. Juniperus & 9 & 2.3 \\
6-7.Picea & 7 & 1.8 \\
6-7. Pinus & 7 & 1.8 \\
8-9. Syringa & 6 & 1.5 \\
8-9. Rosa & 6 & 1.5 \\
10-11. Fraxinus & 5 & 1.2 \\
10-11. Artemisia & 5 & 1.2 \\
Total: & 97 & 24.5 \\
\hline
\end{tabular}


In the flora of Almaty throughout the city, woody and shrubby plant species (native and introducents) are represented by 213 species belonging to 87 genera and 38 families. The ratio of introduced species $(159 ; 74,6 \%)$ between the encountered tree and shrub life forms is shown in Fig. 7 and is 127 species (trees) (59,6\%) and 32 species (shrubs) or $15,0 \%$ respectively (Fig. 7).

\section{Geographical Analysis}

The selection of habitat types was based on the analysis of the current distribution of species]. The spectrum of geographical elements of the urban floras of Almaty shows prevalence of species with wide ranges. In this spectrum, the leading position is occupied by the Holarctic, Palearctic, North American, cosmopolitan, East Asian, Eurasian, European, Mediterranean and mountain of Central Asian groups.

Introductions occurring in tree and shrub plantings of Almaty have different centers of origin (Fig. 8). As can be seen from Fig. 8, among woody-shrub introductions, sharply distinguished by species wealth are species from Asia (27,0\%) (Ailanthus altissima, Phellodendron amurense, Salix matsudana, Acer ginnala, Kerria japonica, Cotoneaster lucidus, Cerasus tomentosa, Chaenomeles speciosa, Salix babylonica, Juglans mandshurica, Forsythia intermedia), North America $(17,0 \%)$ (Acacia albida, Acer saccharinum, Acer negundo, Crataegus horrida, Populus deltoides, Populus balsamifera, Juglans nigra, Juglans cinerea, Mahonia aquifolium, Picea glauca, Picea pungens, Picea engelmannii, Pseudotsuga menziesii, Pinus sponderosa, Tsuga Canadensis, Fraxinus lanceolata), of Europe $(13,8 \%)$ (Euonymuseuropaea, Acer pseudoplatanus, Sorbus aucuparia, Crataegus monogina, Tilia platyphyllos, Tilia cordata, Picea abies, Pinus mugo) and the Palearctic (6,2\%) (Viburnum opulus, Spiraea vanhouttei, Padus avium, Salix alba, Populus alba, Populus nigra, Buxus sempervirens, Sambucus nigra, Cotinus coggygria and other).

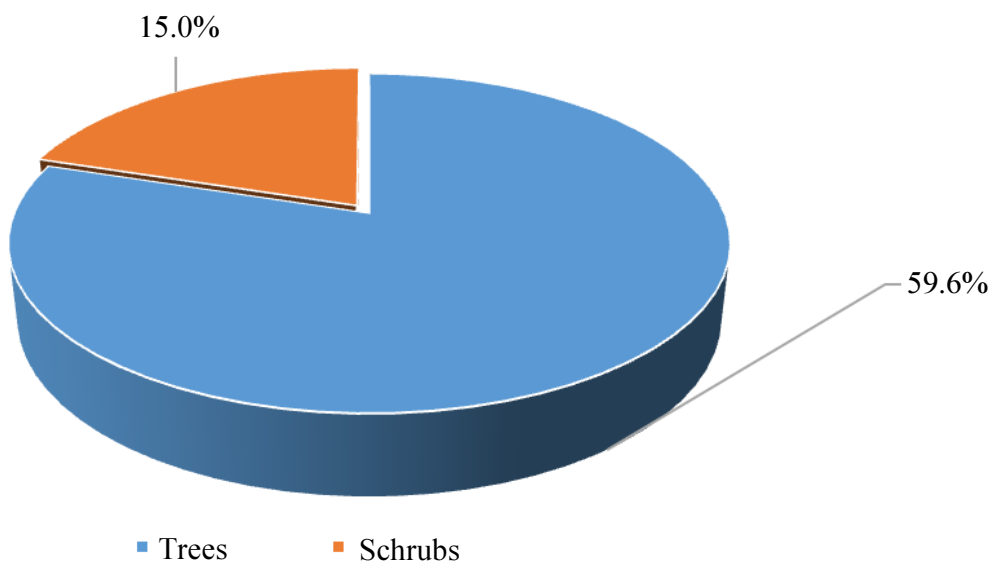

Fig. 7: The ratio of introduced wood and shrub forms

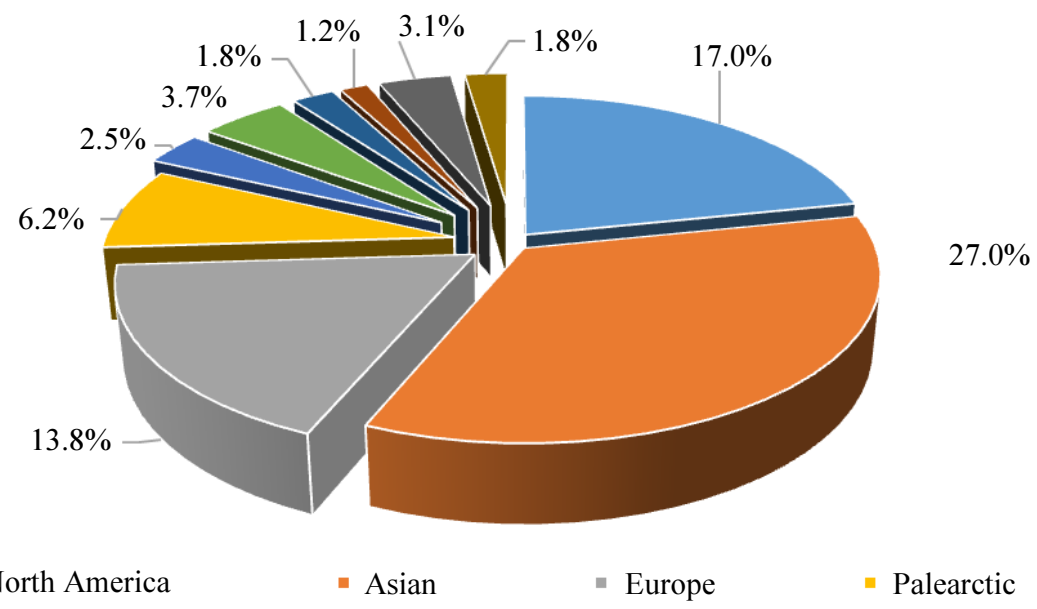

Fig. 8: Distribution of woody-shrubby species-introducents by centers of origin 
A small percentage of species belongs to Eurasia $(3,7 \%)$ (Cornus alba, Frangula alnus, Acer mono, Acer platanoides, Populusitalica), Caucasus and Crimea (1,2\%) (Pinus pallasiana, Amelanchier spicata), Mediterranean $(3,1 \%)$ (Pinus nigra, Fraxinus excelsior, Fraxinus rotundifolia, Ligustrum vulgare, Syringa vulgaris,) and Holarctic (2,5\%) (Swida alba, Aesculus hippocastanum, Grossulariauva-crispa).

\section{Biomorphological Analysis}

The study of urban flora and its biomorphological structure reflects the nature of the adaptation of plants to a set of environmental conditions that have evolved in certain ecotopes. Therefore, its analysis is the main tool in understanding the ecology of plant habitats. The basis for the analysis of life forms in our studies was the system of life forms Serebryakov and Raunkire (Serebryakov, 1962). Analysis of life forms by Serebryakov (1962) showed that in the urban flora of Almaty, herbaceous plants predominate - $183(46,1 \%)$ (polycarpics and monocarpics). The leading position is occupied by the group of herbaceous polycarpicons - 112 species or $28,2 \%$, among which the group of longcrowned plants - 18,4\% (Bromopsisinermis, Dactilysglomerata, Festuca pratensis, etc.), which have the maximum capacity for vegetative growth and reproduction and are characterized by rapid seizure of the territory (Fig. 9). The other group consists of species that are not capable of active vegetative propagation: rod-root, short-rooting and tuber-forming species - 45 species $(11,4 \%$ of the total number of species). Participation in the flora of root-plant plants is insignificant. Among them are representatives of the family Fumariaceae. Monocarpics number 71 species $(18,0 \%)$. Their life cycle they pass in one or two years, ending it with flowering, fruiting and dying. The share of this group in the flora is explained by the prolonged and intensive anthropogenic impact on the vegetation cover of the studied territory. As a rule, these are weeds, among which the annual herbs - Capsella bursa-pastoris, Lepidium ruderale, etc. are widespread. The most numerous group among the urban flora are the Phanerophytes and the Chamefytes - 213 species or $53,7 \%$. The group of phanerophytes is well represented in the families Oleaceae ( 5 species), Rosaceae (29 species), Ulmaceae (5 species), Pinaceae (20 species), Salicaceae (12 species), Aceraceae (8 species), Betulaceae (4 species), Fabaceae 4 species), Elaeagnaceae (4 species), Juglandaceae (4 species), Anacardiaceae (3 species).

Among them, about 20 species are cultivated: Berberis vulgaris, Grossulariauva-crispa, Malus domestica, Fraxinus pensylvanica and others. The group of chamefites in the urban flora of Almaty is widely found in the families of Rosaceae (40 species), Berberidaceae (5 species), Cupressaceae (8 species), Oleaceae (8 species), Grossulariaceae (4 species), Caprifoliaceae (6 species), Fabaceae (4 type). The second place in the investigated urban flora is occupied by herbaceous perennials of 112 species of hemicalcryptophytes $(28,2 \%)$, which is typical of the moderately cold zone and a small percentage of terrophytes of about $15,0 \%$, indicating the preservation of the natural core of the flora. The hemi-cryptophyte group is most widely found in the families Asteraceae (26 species), Poaceae (9 species), Lamiaceae (9 species), Fabaceae (7 species), Rosaceae (7 species), Malvaceae (6 species), Polygonaceae (6 species) and others. The leading position after hemi-cryptophytes is occupied by herbaceous monocarpicles $-18,0 \%$, among which are annuals $-13,7 \%$. The monocarpic group is found in the families of Brassicaceae (5 species), Poaceae (7 species), Asteraceae (8 species), Boraginaceae (2 species), Malvaceae (2 species), Balsaminaceae (2 species), Chenopodiaceae (2 species), Scrophulariaceae species), Caryophyllaceae (2 species), Solanaceae (2 species), Cuscutaceae (2 species) and others.

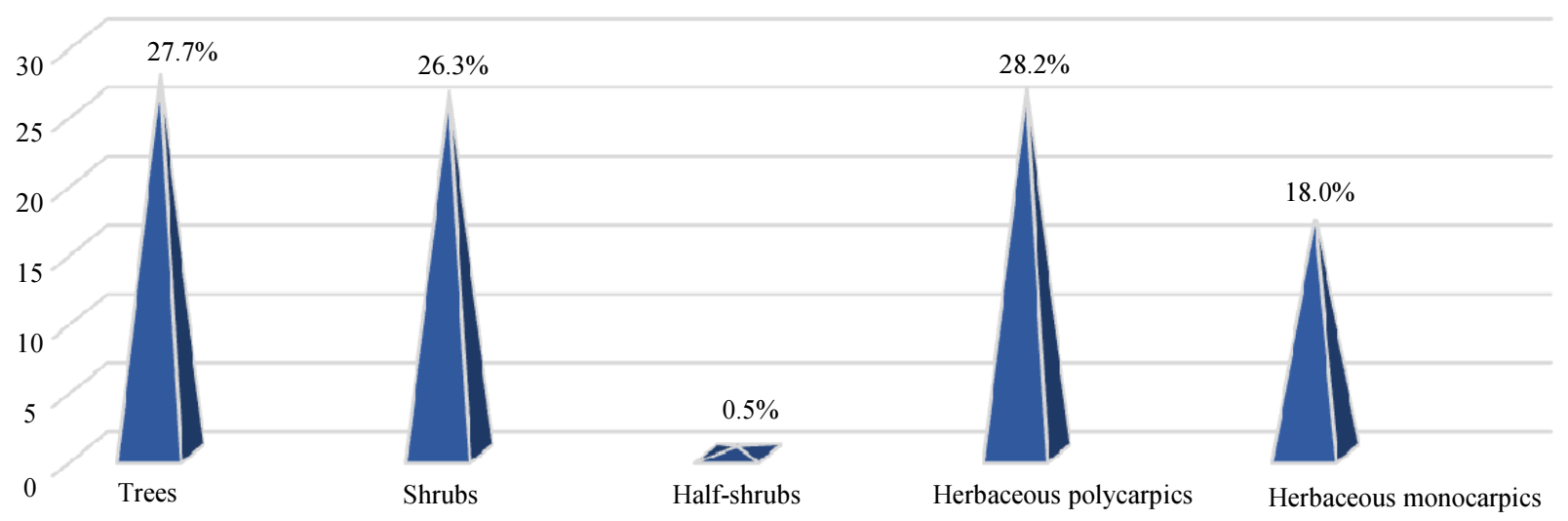

Fig. 9: Distribution of life forms of urban floras in Almaty 
As a result of our research it was revealed that only $25 \%$ of the species diversity of local wood and shrub plants is used in the gardening of Almaty. Natural and climatic conditions of the city of Almaty allow to significantly expand the assortment for planting the city, both at the expense of local and due to introduced wood and shrub plants. It should be noted that for today the weak places of gardening in Almaty are its monotony, that is, mostly the northern breeds of mass assortment predominate in gardening and there is no assortment of plants of local southern color, which should become the main goal of landscapers in the future when creating new and reconstructing old ones landings; the absence of special landscape solutions for the greening of motorways at the entrance to the city, as well as new areas where local ornamental grasses, beautifully flowering shrubs (species, varieties and forms of Spiraeahypericifolia, Berberis iliensis, Berberis heteropoda, Lonicera altmanni, Lonicera alberti, Caragana turkestanica) and trees (Armeniaca vulgaris, Cerasus tianschanica, Cerasus erythrocarpa, Prunus sogdiana) will give a special color scale and underline the southern color of the landscape complex of Almaty. We are recommended in green construction in Almaty, parks, squares, boulevards and green areas using local tree and shrub species of the natural flora of Kazakhstan, which includes about 232 taxa. The recommended species of local woody and shrubby plants for beauty and high decorative qualities are superior to the introduced plants currently used for landscaping of the city of Almaty. Expansion of the range of local woody and shrubby plant species in the gardening of the city of Almaty promotes the promotion and conservation of the biodiversity of the natural flora of the Republic of Kazakhstan.

\section{Weed Element of the Flora of Almaty City}

The weed element of the flora of Almaty is represented by 68 species or $17.7 \%$ belonging to 54 genera and 20 families.

Analysis of the leading families of weedy species in Almaty showed that the largest families are Asteraceae (17; 4.3\%), Poaceae (15; 3.7\%), Brassicaceae (2.2\%), Fabaceae (3;0.75\%), Chenopodiaceae (3, 0.75\%). In 2 species $(0.5 \%)$ contain 6 families: Polygonaceae, Urticaceae, Balsaminaceae, Solanaceae, Plantaginaceae, Boraginaceae and in 1 species contain 9 families. These include: Ranunculaceae, Papaveraceae, Portulacaceae, Amaranthaceae, Primulaceae, Malvaceae, Cannabaceae, Convolvulaceae, Apiaceae. Among the weed plants, by the degree of naturalization, the species prevail, a significant part of which is unintentionally distributed and actively settling on disturbed habitats. These are such widely distributed weeds and ruderal plants as Amaranthus retroflexus, Atriplex calotheca, Chenopodium album, Ch. hybridum, Sisymbrium loeseli, Plantago major, $P$. lanceolata, Cirsium arvense, Cichorium intybus, Bromus japonicus, Hyoscyamus pusillus, Ambrosia artemisiifolia, Thlaspi arvense, Datura stramonium, Abutilon theophrasti, Solanum nigrum, Cynodon dactylon, Urtiva dioica, Capsella bursa-pastoris, Artemisia vulgaris, Artemisia annua, Artemisia absinthium, Arctium tomentosum, Eragrostis minor, Convolvulus arvensis, Xanthium strumarium and others.

\section{Conclusion}

To date, the flora of the country's largest metropolis has not been the object of a special floristic study, so it became necessary to study it in detail.

In the gardening of Almaty, there are 54 species (25.3\%) of trees and shrubs of the local (natural) flora of Kazakhstan ( 9 coniferous and 45 hardwoods) from 33 genera and 19 families in the gardening of Almaty 159 species $(74.6 \%)$ of woody and shrub introducents are used, that is, plants grown in the soil outside the range of their natural distribution. Of these, 22 are coniferous and 137 hardwoods of 61 genera and 34 families. Introducents, found in tree and shrub plantations of Almaty, have different centers of origin: Asia (27.0\%), North America (17.0\%), Europe (13.8\%) and the Palearctic (6.2\%) stand out because of their wealth. A small percentage of species are in Eurasia, the Holarctic, the Caucasus-Crimea, the Far East and the Mediterranean. The basis of the urban flora of the city of Almaty is angiosperms $(92.0 \%)$, gymnosperms are represented in the flora in 31 species $(7.8 \%)$ and 1 species represented by ferns $(0.25 \%)$. The class Liliopsida (monocots) is represented by 4 families or 5.4\%. Class Magnoliopsida (dicotyledonous) is represented by 67 families or $91.7 \%$. The 232 species of arboreal and shrub plants of the natural flora recommended by us expand and diversify the assortment of green plantings in Almaty.

\section{Acknowledgements}

The work was carried out within the framework of the grant "Flora of Urbanized Ecosystem of Almaty".

\section{Author's Contributions}

All authors equally contributed in this work.

\section{Ethics}

This article is original and contains unpublished material. The corresponding author confirms that all of the other authors have read and approved the manuscript and there are no ethical issues involved. 


\section{References}

Abdulina, S.A., 1998. Vascular plants of Kazakhstan. 1st Edn., UrO RAN, Almaty, pp: 188.

Cherepanov, S.K., 1981. Vascular Plants of the USSR. 1st Edn., Nauka, Leningrad, pp: 509.

Flora of Kazakhstan, 1956-1966. Science, Alma-Ata.

Flora of the USSR, 1934-1964. The USSR AS. Moscow.

Goloskokov, V.P., 1949. Flora and vegetation of the highland belts of the Trans-Ili Alatau. 1st Edn., AN KazSSR, Alma-Ata, pp: 203.

Illustrated determinant of plants in Kazakhstan, 1962-1975. Nauka, Alma-Ata.

Kamelin, R.V., 1990. Flora of SyrdaryaKaratau: Materials for Floristic Zoning of Central Asia. 1st Edn., Nauka, Leningrad, pp: 145.

Lavrenko, E.M. and N.I. Nikolskaya, 1963. Areas of some Central Asian and Northwestern types of desert plants and the question of the botanicalgeographical boundary between Central Asia and Central Asia. Bot. J., 48: 1741- 1761.

Lukhtanov, A.A., 2014. The City of Verny and Semirechye Region. 1st Edn., Kazakh Encyclopedia, Almaty, pp: 380 .

Parks and public gardens of Almaty 1917-1991 (Collection of archival documents). Almaty.

Plants of Central Asia, 1963-1989. Nauka. Moscow.

Serebryakov, I.G., 1962. Ecological Morphology of Plants. 1st Edn., Moscow, pp: 378.
Skvortsov, A.K., 1977. Herbarium. 1st Edn., Nauka, Moscow, pp: 199.

The Almaty-2020 Development Program. http://almaty.gov.kz/page.php?page_id=3239\&lang=1

The determinant of plants in Central Asia, 1968-1993. FAN. Tashkent.

The population of Almaty is approaching 2 million people. https://www.nur.kz/1550983-chislennostnaseleniya-almaty-pribli.html.

The determinant of plants on-line. An open atlas of vascular plants in Russia and neighboring countries. http://www.plantarium.ru

The territorial body of the Federal State Statistics Service for the Republic of Mari El. http://maristat.gks.ru/wps/wcm/connect/rosstat_ts/m aristat/resources/.pdf

Tolmachev, A.I., 1974. Introduction to Plant Geography. 1st Edn., Izdatelstvo LGU, Leningrad, pp: 244.

Trees and shrubs of Kazakhstan, 1966. Kainar. Alma-Ata.

Trees and shrubs of the USSR, 1966. Thought, Moscow.

What will save Almaty from smog, 2016. Date View January 11, 2018. https://tengrinews.kz/kazakhstan_news/chto-spasetalmatyi-ot-smoga-307243/

Yurtsev, B.A. and R.V. Kamelin, 1987. The outline of the system of basic concepts of floristics. Theoretical and methodical problems of comparative floristics. Leningrad. 